\title{
Pemberdayaan Kelompok Sadar Wisata (POKDARWIS) Desa Burai melalui Edukasi Protokol Kesehatan COVID-19 Menggunakan Whatsapp
}

\author{
Sri Utami ${ }^{\text {* }}$, Indri Paradillah ${ }^{2}$, Oktrina Gustanela ${ }^{3}$, Jessica Ginting ${ }^{4}$, Hadi Pratomo ${ }^{5}$ \\ Universitas Indonesia, Jl. Margonda Raya, Jawa Barat, Indonesia \\ * Corresponding Author Email: sriutamiogo6@gmail.com, Telp:+6282186869083
}

Received: 12 January 2021; Revised: 22 January 2021; Accepted: 22 January 2021

\begin{abstract}
Abstrak: COVID-19 hingga saat ini masih menjadi masalah kesehatan masyarakat yang serius dan telah menyebar luas hampir seluruh negara di dunia dan ditetapkan sebagai pandemi. Pandemi juga membawa dampak pada perekonomian, termasuk di Desa Burai yang merupakan salah satu tempat wisata yang ada yang mana tempat wisata memiliki resiko tinggi terhadap penyebaran virus COVID-19. Penelitian ini untuk mengetahui gambaran pegetahuan, sikap, dan tindakan, serta menilai efektifitas edukasi terhadap kelompok terkait penerapan protokol kesehatan COVID-19 sebagai bentuk pecegahan pada Kelompok Sadar Wisata (POKDARWIS) di Desa Wisata Burai, Sumatera Selatan Tahun 2020. Metode penelitian menggunakan penelitian kualitatif dan metode kegiatan yang digunakan dalam penelitian ini ialah Model Aksi Komunitas atau Community Action Model (CAM), penelitian dilakukan secara online menggunakan media sosial whatsapp. Kegiatan ini disambut baik oleh anggota POKDARWIS. Berdasarkan hasil penelitian menunjukkan bahwa kegiatan edukasi penerapan protokol COVID-19 ini mampu meningkatkan pengetahuan dan perubahan sikap serta perilaku peserta kegiatan yang sebelumnya tidak tahu atau apatis terhadap COVID-19 menjadi tahu. Melalui edukasi yang telah diberikan anggota kelompok sadar wisata kini dapat turut aktif dalam melakukan pencegahan penyebaran COVID-19 dengan menerapkan protokol kesehatan COVID-19 di desa burai.
\end{abstract}

Kata Kunci: COVID-19, Edukasi Kesehatan, Kelompok Sadar Wisata, Pemberdayaan Kesehatan, Grup Whatsapp

\section{Empowerment of Tourism Awareness Groups (POKDARWIS) in Burai Village through COVID-19 Health Protocol Education Using Whatsapp}

\begin{abstract}
COVID-19 is still a serious and widespread public health problem that has hit almost all countries in the world and has been declared as pandemic. The pandemic has also had an impact on the economy, including in Burai Village which is one of the existing tourist attractions where tourist attractions have a high risk of spreading the COVID-19 virus. This study is to describe knowledge, attitudes, and actions, as well as assess the effectiveness of education for groups related to the implementation of the COVID-19 health protocol as a form of prevention in community of ecotourism (POKDARWIS) in the tourist village of Burai, South Sumatra in 2020. The research method used qualitative research. and the activity method used in this research is the Community Action Model (CAM), the research was conducted online using whatsapp social media. This activity was welcomed by the member of POKDARWIS, The results of this educational activity succeeded in increasing the knowledge of activity participants and changing attitudes and behavior of activity participants who previously did not know or were apathetic about COVID-19 to know. Through this education the member of POKDARWIS can be participate actively in preventing the spread of COVID-19 by implementing health protocols in Burai Village.
\end{abstract}

Keywords: COVID-19, Health Education, Ecotourism Community, Health Empowerment, Whatsapp Group

How to Cite: Utami S, Paradillah, Gustanela O, Ginting J, Pratomo H. (2021). Pemberdayaan Kelompok Sadar Wisata (POKDARWIS) Desa Burai melalui Edukasi Protokol Kesehatan COVID-19 Menggunakan Whatsapp. JPPM (Jurnal Pendidikan dan Pemberdayaan Masyarakat), 8(1), 95-108. Doi: https://doi.org/10.21831/jppm.v8i1.37730 
JPPM (Jurnal Pendidikan dan Pemberdayaan Masyarakat), 8 (1), 2021 - 96

Sri Utami, Indri Paradillah, Oktrina Gustanela, Jessica Ginting, Hadi Pratomo

\section{PENDAHULUAN}

Awal tahun 2020 dunia digemparkan dengan merebaknya virus baru yaitu corona virus jenis baru (SARS-COV-2). Diketahui asal mula virus ini berasal dari Wuhan, Tiongkok. Pada tanggal 31 Desember 2019, Tiongkok melaporkan kasus pneumonia misterius yang tidak diketahui penyebabnya (Burhan, 2020). Pada tanggal 11 Februari 2020, World Health Organization (WHO) memberi nama virus baru tersebut Severa Acute Respiratory Syndrome Coronavirus-2 (SARS-CoV-2) dan nama penyakitnya sebagai Coronavirus Disease 2019 (COVID19) (World Health Organization, 2020).

Coronavirus Disease 2019 (COVID-19) adalah penyakit menular yang disebabkan oleh Severe Acute Respiratory Syndrome Coronavirus 2 (SARS-CoV-2). SARS-CoV-2 merupakan corona virus jenis baru yang belum pernah diidentifikasi sebelumnya pada manusia. Setidaknya ada dua jenis coronavirus yang diketahui menyebabkan penyakit yang dapat menimbulkan gejala berat seperti Middle East Respiratory Syndrome (MERS) dan Severe Acute Respiratory Syndrome (SARS). Tanda dan gejala umum infeksi COVID-19 antara lain gejala gangguan pernapasan akut seperti demam, batuk, dan sesak napas. Masa inkubasi rata-rata 5-6 hari dengan masa inkubasi terpanjang 14 hari. Pada kasus COVID-19 yang berat dapat menyebabkan pneumonia, sindrom pernapasan akut, gagal ginjal, dan bahkan kematian (Kementerian Kesehatan Republik Indonesia, 2020a).

Kasus-kasus yang ditemukan di luar Tiongkok sampai tanggal 12 Februari 2020 tercatat ada di 28 negara, seperti Amerika, Thailand, Hong Kong, Prancis, Malaysia, Singapura, Taiwan, Macau, Jepang, Korea Selatan, Vietnam, Australia, Nepal dan lainnya (Burhan, 2020). WHO menetapkan COVID-19 sebagai pandemi pada tanggal 11 maret 2020 karena tingkat penyebaran dan keparahannya yang mengkhawatirkan (World Health Organization, 2020). Pada tanggal 2 Maret 2020 Indonesia mengumumkan kasus pertama pasien positif COVID-19 (World Health Organization, 2021a).

Secara global, data per 24 November 2020 yang dilaporkan ke WHO, terdapat 58.900 .567 jiwa kasus COVID-19 yang dikonfirmasi positif, dengan 1.393.305 jiwa kematian (World Health Organization, 2021b). Data yang dilaporkan hingga 24 November 2020 di Indonesia terdapat 506.302 jiwa kasus terkonfirmasi positif dan 16.111 jiwa kematian. Sumatera Selatan berada diurutan ke-14 dengan jumlah konfirmasi kasus positif sebanyak 9.o8o jiwa dan total kematian sebanyak 491 jiwa (Komite Penanganan COVID-19 dan Pemulihan Ekonomi Nasional, 2021).

Pemerintah mengajak masyarakat untuk berupaya mengakhiri pandemi COVID19 dengan menerapkan 3 hal utama, yaitu menjaga iman, aman, dam imun. Iman dimaknai dengan menjalankan ibadah sesuai agama dan kepercayaan masing-masing. Aman diartikan sebagai kepatuhan terhadap protokol kesehatan pencegahan COVID-19 yang dikenal dengan $3 \mathrm{M}$ (memakai masker, menjaga jarak, dan menghindari kerumuman, serta mencuci tangan pakai sabun). Defenisi dari imun ialah harus menjaga imun, seperti mengonsumsi makanan bergizi, menjaga kesehatan mental, wajib berolahraga, dan beristirahat cukup. Pemberian informasi dilakukan melalui kegiatan penyuluhan dan pemanfaatan berbagai media cetak dan elektronik terkait informasi mengenai cara hidup bersih dan sehat, cara meningkatkan kekebalan tubuh, dan pencegahan-pencegahan terhadap COVID-19 (BNPB, 2020).

Dampak COVID-19 di Indonesia tidak hanya pada kesehatan, tetapi berdampak pada aspek politik, ekonomi, sosial, budaya, pertahanan dan keamanan, serta kesejahteraan masyarakat di Indonesia (Kementerian Kesehatan Republik Indonesia, 2020a). Dampak ekonomi salah satunya pada tempat-tempat wisata. Berdasarkan data BPS selama JanuariSeptember 2020 kunjungan wisatawan mancanegara mencapai 3,56 juta kunjungan, angka ini turun $70,57 \%$ dibanding Januari-September 2019 yang mencapai 12,10 juta kunjungan. Wisata mengandung empat unsur, yaitu kegiatan perjalanan, dilakukan secara sukarela, bersifat sementara, serta perjalanan itu seluruhnya atau sebagian bertujuan untuk menikmati objek dan daya tarik wisata (Ali, 2015). Pemberdayaan masyarakat dalam pencegahan COVID-19 adalah semua upaya yang dilakukan oleh semua komponen masyarakat dengan potensi yang 
dibutuhkan oleh komunitas yang diberdayakan dan mampu mendukung dan mencegah transmisi COVID-19 (Kementerian Kesehatan Republik Indonesia, 202ob).

Pentingnya keyakinan individu, nilai-nilai, dan kepercayaan diri dalam menentukan perilaku kesehatan, seperti halnya dengan model keyakinan kesehatan. Teori kognitif sosial memberikan dasar teoritis yang komprehensif dan terintegrasi untuk program promosi kesehatan. Berdasarkan hasil penelitian di Desa Gulingan, Bali menunjukkan bahwa 51,8\% responden berpengetahuan baik, $66,7 \%$ berperilaku baik, dan $56,1 \%$ berpraktik baik dalam pencegahan COVID-19 (Putra, 2020). Penelitian lain menyatakan ada pengaruh penyebaran informasi melalui whatsapp dengan kesiapsiagaan masyarakat terhadap bencana COVID-19 (Dewiyuliana, Septiana, 2020). Penelitian ini bertujuan untuk (1) Mengetahui gambaran efektifitas edukasi pada Kelompok Sadar Wisata (POKDARWIS) dalam penerapan protokol kesehatan COVID-19 melalui aplikasi whatsapp sebagai bentuk pencegahan di Desa Burai, Sumatera Selatan Tahun 2020. (2) Mengetahui gambaran edukasi terhadap peningkatan pengetahuan POKDARWIS dalam penerapan protokol kesehatan COVID-19. (3) Mengetahui gambaran edukasi terhadap peningkatan sikap POKDARWIS dalam penerapan protokol kesehatan COVID-19. (4) Mengetahui gambaran edukasi terhadap peningkatan perilaku POKDARWIS dalam penerapan protokol kesehatan COVID-19.

\section{METODE}

Penelitian ini menggunakan desain penelitian kualitatif yang bertujuan untuk mengetahui gambaran pengetahuan, sikap, dan perilaku mengenai penerapan protokol kesehatan COVID19 pada Kelompok Sadar Wisata (POKDARWIS) di Desa Burai. Kegiatan pemberdayaan dilakukan pada tanggal 29 November 2020 sampai dengan 22 Desember 2020.

Metode pemberdayaan yang digunakan adalah model aksi komunitas atau Community Action Model (CAM) (Murphy, 2012). Terdapat 5 tahapan dalam kegiatan pemberdayaan ini.

1. Dialogue of concern and issues. Sebelum melakukan kegiatan pemberdayaan, langkah pertama yang harus dilakukan adalah mengidentifikasi dan mendeskripsikan masalah kesehatan yang menjadi fokus perhatian masyarakat dimasa pandemi ini. Pandemi COVID19 telah menjadi masalah kesehatan global khususnya di Indonesia. Kasus COVID-19 di Indonesia terus mengalami peningkatan tiap harinya dan perlu berbagai upaya untuk mempercepat penanganan COVID-19.

2. Community diagnosis. Tahap kedua dalam pemberdayaan ini yaitu peneliti melakukan wawancara kepada informan terkait permasalahan kesehatan COVID-19 dan dampaknya terhadap kegiatan wisata yang ada di Desa Burai. Kriteria sumber informan dikategorikan menjadi dua, informan kunci dan informan kunci ahli. Informan kunci ialah orang yang mengetahui secara rinci dan keseluruhan mengenai perilaku dan lingkungan. Pada penelitian ini yang berperan sebagai informan kunci adalah Kepala Desa. Sedangkan, informan kunci ahli merupakan orang yang digali informasinya tentang penelitian yang diangkat serta mau secara sukarela menjadi informan dalam penelitian sesuai dengan karakteristik yang dibutuhkan (Moleong, 2017). Pada penelitian ini yang berperan sebagai informan kunci ahli yakni ketua, wakil ketua, dan anggota POKDARWIS. Tidak hanya wawancara kepada informan, peneliti juga melakukan observasi perilaku Kelompok Sadar Wisata (POKDARWIS) dan observasi lingkungan yang mencerminkan gambaran penerapan protokol kesehatan COVID-19 di Desa Burai.

3. Analysis. Menafsirkan pengamatan dan hasil wawancara serta mengintegrasikan temuan masalah ke dalam rencana yang diusulkan. Setelah dilakukan wawancara kepada informan serta observasi perilaku dan lingkungan, didapatkan gambaran pengetahuan, sikap dan perilaku mengenai COVID-19 pada POKDARWIS dan upaya penanganan COVID-19 yang telah dilakukan oleh pemerintah setempat.

4. Intervention design. Intervensi yang diberikan kepada POKDARWIS adalah edukasi kelompok mengenai penerapan protokol kesehatan COVID-19. Peserta edukasi adalah 
Kelompok Sadar Wisata (POKDARWIS) Desa Burai, Kecamatan Tanjung Batu, Kabupaten Ogan Ilir, Provinsi Sumatera Selatan. Jumlah peserta edukasi sebanyak 20 orang. Metode yang digunakan pada edukasi ini adalah diskusi kelompok melalui media whatsapp. Materi edukasi yang diberikan yaitu mengenai definisi, gejala, cara penularan, dan cara pencegahan COVID-19. Edukasi dilakukan menggunakan aplikasi whatsapp, karena sinyal internet yang kurang mendukung jika harus menggunakan aplikasi komunikasi video seperti zoom dan google classroom. Selain itu, semua anggota POKDARWIS juga memiliki aplikasi whatsapp dan aktif digunakan sebagai media komunikasi antar anggota.

5. Monitoring dan evaluasi. Keberlanjutan setelah edukasi kelompok yakni pemantauan dan evaluasi. Evaluasi yang dilakukan bertujuan menilai apakah kegiatan edukasi yang telah dilaksanakan dapat diaplikasikan pada kegiatan wisata yang dipandu oleh POKDARWIS di Desa Burai. Untuk mengidentifikasinya diajukan beberapa pertanyaan perilaku-perilaku dalam kegiatan wisata yang telah dilakukan sebagai upaya pencegahan COVID-19 dan pemilihan video protokol kesehatan COVID-19 terbaik. Sebagai apresiasi dalam kegiatan edukasi, turut dilakukan juga pemilihan best participant dan best role model. Peran role model ini nantinya diharapkan dapat menjadi contoh bagi anggota POKDARWIS untuk dapat menerapkan perilaku yang mengarah pada kelompok sehat sebagai upaya pencegahan penularan COVID-19 pada kegiatan ekowisata di Desa Burai.

Data yang digunakan dalam penelitan ini adalah data primer. Data primer berupa data yang diperoleh dari hasil wawancara untuk menggali informasi tentang penerapan protokol kesehatan COVID-19 di Desa Burai, observasi perilaku dan lingkungan serta kuesioner. Pengukuran peningkatan pengetahuan dan sikap dilakukan dengan membagikan pretest sebelum edukasi dan posttest setelah edukasi. Pengukuran perilaku dilihat dari video pencegahan COVID-19 yang dikirimkan peserta. Efektivitas penggunaan media whatsapp dinilai dari keaktifan peserta dalam memberikan respon selama edukasi dan jumlah pertanyaan yang diajukan.

\section{HASIL DAN PEMBAHASAN}

Pemberdayaan masyarakat ialah suatu upaya atau proses untuk menumbuhkan kesadaran, kemauan, dan kemampuan masyarakat dalam mengenali, mengatasi, memelihara, melindungi dan meningkatkan kesejahteraan mereka sendiri. (Notoatmodjo, 2012). Pemberdayaan atau empowerment berarti proses pemberian daya atau kekuatan kepada individu/kelompok (Ningrum \& Sujarwo, 2017). Pemberdayaan masyarakat pada dasarnya merupakan strategi perubahan sosial secara terencana yang ditujukan untuk mengatasi masalah atau memenuhi kebutuhan masyarakat (Saugi \& Sumarno, 2015).

Pemberdayaan merupakan sebuah upaya untuk memberikan kekuatan atau daya untuk masyarakat dengan memanfaatkan kemampuan dan potensi yang dimiliki oleh masyarakat (Miradj \& Sumarno, 2014). Suatu kegiatan atau program dapat dikategorikan ke dalam pemberdayaan masyarakat apabila kegiatan tersebut tumbuh dari bawah dan non instruktif serta dapat memperkuat, meningkatkan, atau mengembangkan potensi masyarakat setempat, guna mencapai tujuan yang diharapkan. (Notoatmodjo, 2012)

Metode pemberdayaan yang digunakan pada penelitian ini adalah model aksi komunitas atau Community Action Model (CAM) (Murphy, 2012). Terdapat 5 tahapan dalam metode CAM ini yaitu dialogue of concern and issues, community diagnosis, analysis, intervention design serta monitoring dan evaluasi.

Tahap pertama metode CAM adalah dialogue of concern and issues. Sebelum melakukan kegiatan pemberdayaan, langkah pertama yang harus dilakukan adalah mengidentifikasi dan mendeskripsikan masalah kesehatan yang menjadi fokus perhatian masyarakat di masa pandemi ini. Peningkatan kasus COVID-19 yang terus terjadi di Indonesia menjadi fokus permasalahan kesehatan saat ini. Kasus COVID-19 harus segera diatasi mengingat dampak yang disebabkan tidak hanya pada sektor kesehatan, namun berdampak pula pada aspek politik, ekonomi, sosial, 
budaya, pertahanan dan keamanan, serta kesejahteraan masyarakat di Indonesia (Kementerian Kesehatan Republik Indonesia, 2020a). Kegiatan ekowisata yang berlangsung di Desa Burai dihentikan sementara karena adanya kebijakan karantina wilayah Desa Burai sehingga tidak ada warga dari luar yang datang ke Desa Burai.

Tahap kedua dari CAM yakni community diagnosis. Pada tahap ini peneliti melakukan wawancara kepada informan terkait permasalahan kesehatan COVID-19 dan dampaknya terhadap kegiatan wisata yang ada di Desa Burai.

Kriteria sumber informan dikategorikan menjadi dua, informan kunci dan informan kunci ahli. Pada penelitian ini yang berperan sebagai informan kunci adalah Kepala Desa. Sedangkan yang berperan sebagai informan kunci ahli yakni ketua, wakil ketua, dan anggota POKDARWIS.

Sebelum dilakukan wawancara, informan terlebih dahulu membaca dan menandatangani informed consent sebagai bukti kesediaan menjadi informan dalam penelitian. Adapun, karakteristik informan dapat dilihat pada tabel 1.

Tabel 1. Karakteristik Informan

\begin{tabular}{cccccc}
\hline No. & Inisial & Umur & L/K & $\begin{array}{c}\text { Pendidikan } \\
\text { Terakhir }\end{array}$ & Pekerjaan \\
\hline 1. & ES & 37 & L & D-3 & Kades \\
2. & FHS & $\mathbf{2 9}$ & L & D-3 & Mahasiswa \\
3. & DK & $\mathbf{2 3}$ & L & SMA & Mahasiswa \\
4. & AA & $\mathbf{2 2}$ & L & S-1 & Guru \\
\hline
\end{tabular}

Karakteristik informan dipilih secara purposive sampling dengan kriteria yang sudah ditetapkan yaitu masyarakat di Desa Burai yang mengetahui informasi kesuluruhan kegiatan wisata yaitu sebanyak 4 orang. Hasil pada tabel 1 menunjukkan bahwa keseluruhan informan adalah laki-laki dengan rentang usia 22 tahun hingga 37 tahun dan pendidikan terakhir yakni SMA, D-3, dan S1.

Tidak hanya wawancara kepada informan, peneliti juga melakukan observasi perilaku Kelompok Sadar Wisata (POKDARWIS) dan observasi lingkungan yang mencerminkan gambaran penerapan protokol kesehatan COVID-19 di Desa Burai. Observasi perilaku berupa pengamatan situasi POKDARWIS, masyarakat di Desa Burai dan pengunjung wisata. Berdasarkan hasil observasi didapatkan gambaran bahwa masih terdapat anggota kelompok POKDARWIS, masyarakat, dan pengunjung wisata yang tidak memakai masker, tidak menjaga jarak aman dan tidak mendukungnya sarana penerapan protokol kesehatan di objek yang menjadi tempat wisata, seperti tidak ada sabun cuci tangan dan tidak adanya air di tempat cuci tangan. Hal ini mencerminkan perilaku yang tidak sehat dan masih minimnya kesadaran untuk menerapkan protokol kesehatan COVID-19.

Tahap ketiga dari CAM adalah analysis. Setelah melakukan kegiatan wawancara dan observasi, dilakukan analisis untuk menafsirkan hasil temuan yang kemudian akan disusun kegiatan pemberdayaan yang sesuai dengan situasi kesehatan dan kondisi POKDARWIS saat ini.

Setelah analisis dilakukan, langkah selanjutnya yaitu intervention design. Intervensi yang diberikan kepada POKDARWIS adalah edukasi kelompok mengenai penerapan protokol kesehatan COVID-19. Peserta edukasi adalah Kelompok Sadar Wisata (POKDARWIS) Desa Burai, Kecamatan Tanjung Batu, Kabupaten Ogan Ilir, Provinsi Sumatera Selatan. Jumlah peserta edukasi sebanyak 20 orang. Berikut ini karakteristik responden berdasarkan jenis kelamin, umur, tingkat pendidikan dan status pekerjaan.

Tabel 2. Distribusi Responden Berdasarkan Jenis Kelamin

\begin{tabular}{ccc}
\hline Jenis Kelamin & Frekuensi & $\begin{array}{c}\text { Persentase } \\
\mathbf{( \% )}\end{array}$ \\
\hline Laki-Laki & 8 & $40 \%$ \\
Perempuan & 12 & $60 \%$ \\
Total & 20 & $100 \%$ \\
\hline
\end{tabular}


JPPM (Jurnal Pendidikan dan Pemberdayaan Masyarakat), 8 (1), 2021 - 100

Sri Utami, Indri Paradillah, Oktrina Gustanela, Jessica Ginting, Hadi Pratomo

Tabel 2 menunjukkan bahwa mayoritas responden adalah perempuan. Terdapat 12 responden berjenis kelamin perempuan dengan persentase $60 \%$ dan 8 responden berjenis kelamin laki-laki dengan persentase $40 \%$.

Tabel 3. Distribusi Responden Berdasarkan Umur

\begin{tabular}{|c|c|c|c|c|}
\hline \multirow{2}{*}{ Variabel } & \multicolumn{4}{|c|}{$\underline{\text { Usia (tahun) }}$} \\
\hline & Mean & SD & Minimum & Maksimum \\
\hline Umur & 20 & 3,86 & 15 & 29 \\
\hline
\end{tabular}

Tabel 3 menunjukkan bahwa rata-rata anggota POKDARWIS berusia 20 tahun, dengan usia terendah yaitu 15 tahun dan usia tertinggi 29 tahun.

\begin{tabular}{ccc} 
Tabel 4. Distribusi Responden Berdasarkan Tingkat Pendidikan \\
\cline { 2 - 3 } $\begin{array}{c}\text { Tingkat } \\
\text { Pendidikan }\end{array}$ & Frekuensi & Persentase (\%) \\
\hline SMA & 18 & \\
D 3 & 1 & $90 \%$ \\
S1 & 1 & $5 \%$ \\
Total & $\mathbf{2 0}$ & $5 \%$ \\
& & $\mathbf{1 0 0} \%$ \\
\hline
\end{tabular}

Berdasarkan tabel 4 diatas, didapatkan hasil bahwa mayoritas anggota POKDARWIS memiliki tingkat pendidikan terakhir SMA. Terdapat 90\% responden dengan tingkat pendidikan SMA, 5\% responden dengan tingkat pendidikan $\mathrm{D}_{3}$ dan $5 \%$ responden dengan tingkat pendidikan $\mathrm{S}$.

Tabel 5. Distribusi Responden Berdasarkan Status Pekerjaan

\begin{tabular}{ccc}
\hline Status Pekerjaan & Frekuensi & Persentase (\%) \\
\hline Pelajar/Mahasiswa & 12 & $60 \%$ \\
Bekerja & 4 & $20 \%$ \\
Tidak Bekerja & 4 & $20 \%$ \\
Total & $\mathbf{2 0}$ & $\mathbf{1 0 0} \%$ \\
\hline
\end{tabular}

Tabel 5 diatas menunjukkan bahwa mayoritas anggota POKDARWIS adalah pelajar atau mahasiswa. Terdapat 12 responden masih berstatus pelajar/mahasiswa dengan persentase $60 \%$, 4 responden yang bekerja dengan persentase $20 \%$ dan 4 responden yang tidak bekerja dengan persentase $\mathbf{2 0} \%$. Kegiatan edukasi kelompok dilakukan pada bulan Desember 2020 pada masa pandemi COVID-19. Evaluasi kegiatan intervensi dinilai dari dua aspek yakni evaluasi penggunaan whatsapp sebagai media edukasi kelompok dan penilaian pengetahuan, sikap dan perilaku terkait penerapan protokol Kesehatan

\section{Efektivitas Media Whatsapp}

Aplikasi whatsapp dipilih karena aplikasi ini dimiliki dan digunakan oleh seluruh anggota POKDARWIS. Penyampaian materi edukasi dilakukan oleh mahasiswa Pascasarjana Departemen Pendidikan Kesehatan dan Ilmu Perilaku, Fakultas Kesehatan Masyarakat, Universitas Indonesia sebagai pendamping Kelompok Sadar Wisata (POKDARWIS). Untuk mempermudah penyampaian informasi, juga digunakan media bantu berupa poster digital (gambar 1) dan pemutaran video yang disampaikan ketika edukasi kelompok berlangsung. Keberhasilan kegiatan dinilai dari terselenggaranya kegiatan dan antusiasme peserta dalam mengikuti kegiatan edukasi kelompok (gambar 2). Selain menyelenggarakan edukasi penerapan protokol kesehatan COVID-19, juga dilakukan pemberian spanduk (gambar 3), masker dan cairan cuci tangan. 
JPPM (Jurnal Pendidikan dan Pemberdayaan Masyarakat), 8 (1), 2021 - 101

Sri Utami, Indri Paradillah, Oktrina Gustanela, Jessica Ginting, Hadi Pratomo

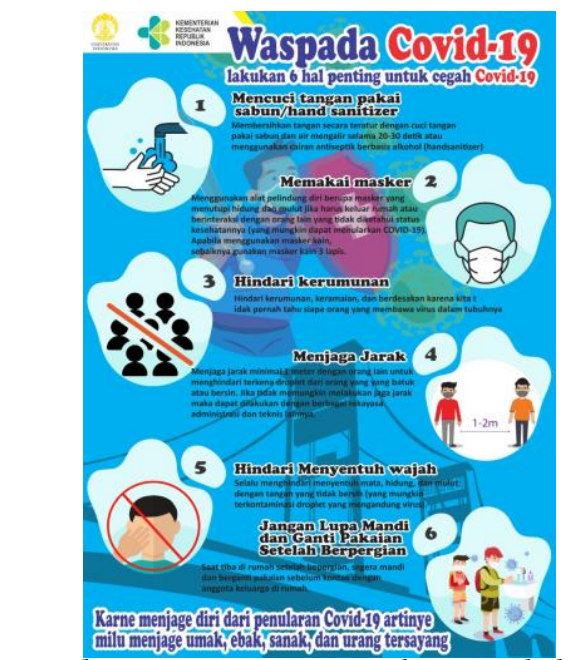

Gambar 1. Poster Digital Penyuluhan
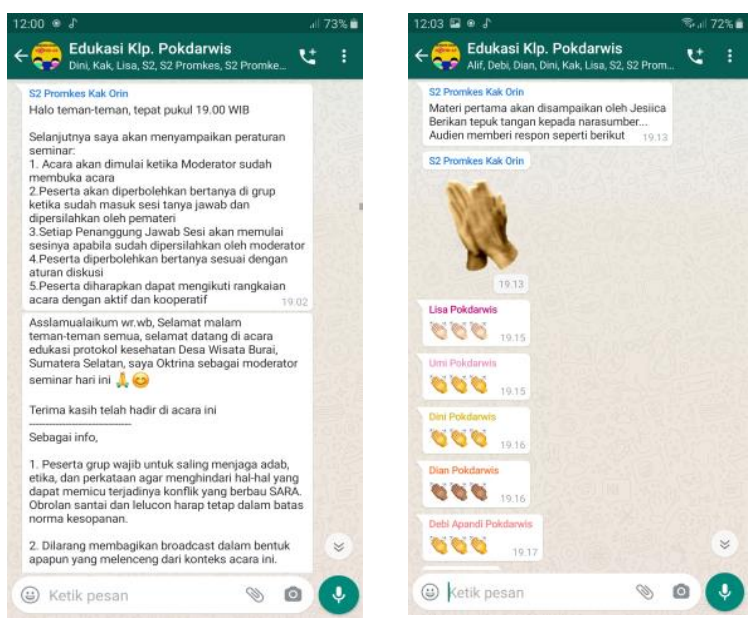

Gambar 2. Kegiatan Edukasi Kelompok Pokdarwis Desa Burai, Sumatera Selatan

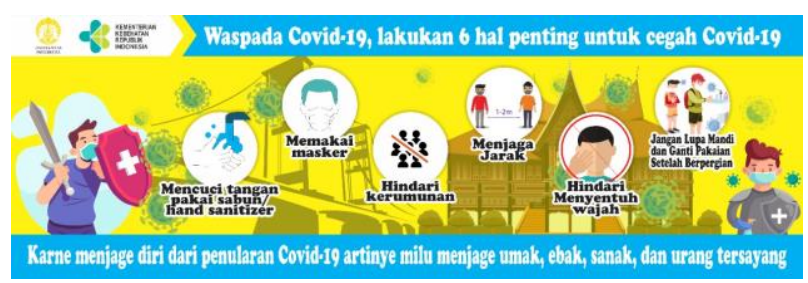

Gambar 3. Spanduk Penyuluhan Pencegahan COVID-19

\section{Pengetahuan}

Pengetahuan merupakan hasil dari tahu, dan ini terjadi setelah orang melakukan pengindraan terhadap suatu obyek tertentu. Pengindraan terjadi melalui pancaindra manusia, yakni indra penglihatan, pendengaran, penciuman, rasa, dan raba. Sebagian besar pengetahuan manusia diperoleh melalui mata dan telinga (Notoatmodjo, 2012). 
JPPM (Jurnal Pendidikan dan Pemberdayaan Masyarakat), 8 (1), 2021 - 102

Sri Utami, Indri Paradillah, Oktrina Gustanela, Jessica Ginting, Hadi Pratomo

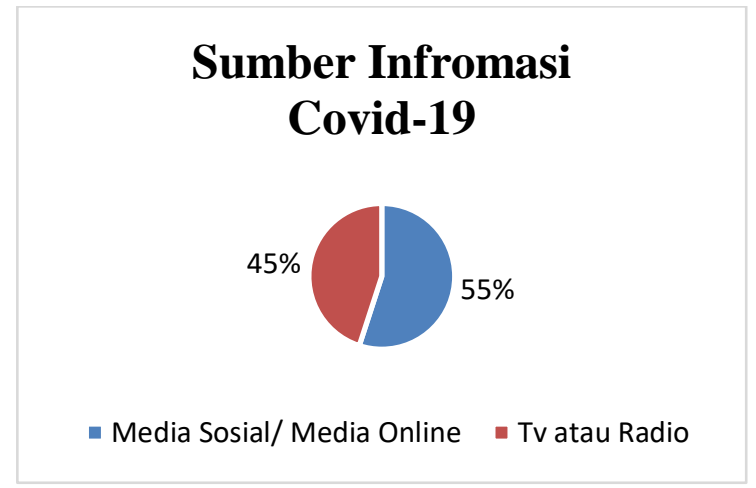

Gambar 4. Sumber Informasi COVID-19

Sebelum dilaksanakan edukasi kelompok, Kelompok Sadar Wisata (POKDARWIS) sudah pernah mendapatkan atau terpapar informasi mengenai COVID-19. Adapun, sumber informasi yang didapatkan dapat dilihat pada gambar 4 . Berdasarkan data tersebut diperoleh hasil bahwa sebesar $55 \%$ responden pernah mendapatkan informasi tentang COVID-19 sebelum dilakukan edukasi dari media sosial atau media online seperti Facebook, Instagram, Youtube, Twitter, dan lain-lain. Hal ini membuktikan bahwa media sosial atau media online saat ini berpengaruh besar terhadap penyampaian informasi. Sumber informasi yang lain diperoleh dari televisi atau radio sebesar $45 \%$.

Berdasarkan wawancara mendalam yang dilakukan bersama informan diperoleh hasil bahwa informan sudah memiliki tingkat pengetahuan yang benar mengenai protokol kesehatan. Informan sudah banyak mendapatkan infromasi terkait pencegahan-pencegahan COVID-19 baik melalui sosialisasi langsung maupun online.

Berdasarkan pretest dan posttest, terdapat 6 orang yang menjadi kriteria eksklusi karena tidak mengisi kuesioner saat posttest. Dari hasil analisis, didapatkan hasil pretest pengetahuan sebesar $86,5 \%$ dan posttest sebesar $88 \%$ (tabel 6). Hal ini menunjukkan adanya peningkatan persentase sebesar $1,5 \%$. Meskipun peningkatan persentase pengetahuan kecil, dapat disimpulkan secara garis besar bahwa peserta edukasi sudah memiliki pemahaman yang benar tentang COVID-19 dibuktikan dengan nilai pretest dan posttest yang mencapai lebih dari $80 \%$.

Pengetahuan responden belum meningkat secara signifikan dapat disebabkan karena sinyal internet peserta edukasi yang kurang mendukung dan sulitnya pengawasan saat edukasi berlangsung. Media whatsapp sebagai media edukasi memiliki kelemahan yaitu tidak bisa memantau peserta edukasi secara aktif dan hanya melihat dari jumlah peserta yang membaca informasi yang dikirimkan.

Tabel. 6 Hasil Pretest dan Postest Pengetahuan

\begin{tabular}{ccc}
\hline \multirow{2}{*}{$\begin{array}{c}\text { Jumlah } \\
\text { Responden }\end{array}$} & \multicolumn{2}{c}{ Pengetahuan } \\
\cline { 2 - 3 } & Pre Test & $\begin{array}{c}\text { Post } \\
\text { Test }\end{array}$ \\
\hline 20 Orang & $86,5 \%$ & $88 \%$ \\
\hline
\end{tabular}

Di era serba digital ini, penggunaan media sosial mempunyai pengaruh yang besar. Media sosial melalui internet memiliki potensi besar untuk melakukan promosi kesehatan dan intervensi kesehatan lainnya, serta lebih mudah untuk menyentuh sasaran pada setiap levelnya (Leonita, E., \& Jalinus, 2018).

Penggunaan media sosial dapat dengan mudah menciptakan suatu forum antar individu satu dengan lainnya. Pemanfaatan media sosial sangat mudah membuat individu berkomunikasi dan berkomentar kemudian bertukar pikiran tentang berbagai topik maupun kasus yang dibahas oleh individu lain. Whatsapp sebagai salah satu media sosial saat ini banyak digunakan untuk kepentingan bersosialisasi maupun sebagai penyampaian pesan baik oleh individu maupun kelompok (Trisnani, 2017). 
JPPM (Jurnal Pendidikan dan Pemberdayaan Masyarakat), 8 (1), 2021 - 103

Sri Utami, Indri Paradillah, Oktrina Gustanela, Jessica Ginting, Hadi Pratomo

Pada masa pandemi seperti ini edukasi daring terutama menggunakan aplikasi whatsapp banyak dipilih untuk menghindari kerumunan dalam penyampaian edukasi kesehatan. Bukti penelitian menyebutkan bahwa adanya hubungan antara penyebaran informasi COVID-19 melalui whatsapp terhadap kesiapsiagaan masyarakat dalam menghadapi COVID-19 (Dewiyuliana, D., \& Septiana, 2020). Kelebihan yang dimiliki media online ini adalah adanya fitur rekam yang dapat disimpan dalam waktu lama dan fitur mengirim file dan video (Putra, 2020).

Berdasarkan hasil wawancara mendalam yang dilakukan bersama informan diperoleh hasil bahwa informan sudah memiliki tingkat pengetahuan yang benar mengenai penerapan protokol kesehatan COVID-19. Berikut kutipan wawancara yang dilakukan bersama informan.

"Protokol kesehatan adalah anjuran yang wajib dilakukan oleh setiap orang guna memutus rantai penularan COVID-19. Protokol kesehatan tersebut ialah memakai masker, cuci tangan pake sabun, jaga jarak minimal 1-2 meter." (DK)

"Protokol kesehatan yaitu memakai masker, mencuci tangan pakai sabun, menjaga jarak, makan makanan bergizi, olahraga." (FHS)

"...Penerapan protokol kesehatan seperti mencuci tangan pakai sabun dengan air mengalir atau membersihkan tangan menggunakan hand sanitizer, memakai masker sesuai standar baik yang sudah terinfeksi maupun yang tidak dan jangan menyentuh wajah dalam keadaan tangan belum dicuci dan dibersihkan selalu menggunakan etika bersin dan batuk ketika ada didekat orang ramai, selalu menjaga jarak ketika di khalayak ramai minimal 1-2 meter, dan terakhir selalu menjaga kebersihan diri dan lingkungan sekitar." (AA)

Penilitian ini menunjukkan bahwa baik responden maupun informan sama-sama memiliki pengetahuan yang baik mengenai protokol kesehatan COVID-19. Paparan media informasi yang telah didapatkan sebelumnya menjadi faktor lingkungan yang berinteraksi kepada individu sehingga menimbulkan suatu proses pembelajaran terkait penerapan protokol kesehatan COVID-19. Hal serupa juga ditemukan dalam penelitian yang dilakukan oleh Budi Yanti et al yang menyatakan bahwa sebanyak 99\% responden yang memiliki tingkat pendidikan tinggi sudah memiliki pemahaman yang baik terkait jaga jarak sebagai bentuk pencegahan COVID-19 (Yanti, 2020).

\section{Sikap}

Hasil penelitian yang dilakukan menunjukkan bahwa reponden sudah memiliki sikap positif terkait penerapan protokol kesehatan Covid-19. Hal ini diperoleh melalui pengisian kuesioner pada pretest edukasi oleh 20 orang responden dan diperoleh data sebesar $86,7 \%$ dan terjadi peningkatan nilai sikap pada post test sebesar $5 \%$ menjadi $91,7 \%$, seperti yang tertera pada tabel 7. Hal ini menggambarkan bahwa kegiatan edukasi yang diberikan memiliki dampak terhadap sikap responden. Perubahan sikap peserta terkait penerapan protokol kesehatan Covid 19 ditunjukkan pada tabel berikut ini.

Tabel 7. Hasil Pretest dan Postest sikap

\begin{tabular}{cc}
\hline \multicolumn{2}{c}{ Sikap } \\
\hline Pre Test & Post Test \\
\hline $86,7 \%$ & $91 \%$
\end{tabular}

Berdasarkan hasil wawancara mendalam yang dilakukan bersama informan diperoleh hasil bahwa informan bersikap positif mengenai penerapan protokol kesehatan COVID-19. Berikut kutipan wawncara bersama informan.

"Bentuk dukungan saya terhadap penerapan protokol kesehatan pencegahan COVID-19 adalah dengan memasang spanduk himbauan mengenai pencegahan terhadap COVID-19 dan mengedukasi kepada keluarga dan masyarakat untuk selalu mentaati protokol 
JPPM (Jurnal Pendidikan dan Pemberdayaan Masyarakat), 8 (1), 2021 - 104

Sri Utami, Indri Paradillah, Oktrina Gustanela, Jessica Ginting, Hadi Pratomo

kesehatan, membagikan masker, dan menyiapkan alat pencuci tangan ditempat tempat umum." (FHS)

"Sebagai masyarakat Indonesia mendukung dan harus selalu mematuhi aturan yang ada dari pihak pemerintah apalagi sekarang kita hidup berdampingan dengan virus baru untuk mencegah diri terkena virus tersebut sebaiknya mengikuti protokol kesehatan yang dicanangkan pemerintah demi kebaikan bersama." (AA)

"Bentuk dukungan yang saya lakukan terhadap penerapan protokol kesehatan ada 2: pertama, menjadi individu yang selalu menerapkan protokol kesehatan dengan memakai masker saat keluar rumah cuci tangan pakai sabun saat pulang ke rumah dan selalu jaga jarak aman 1-2 meter. kedua, selalu mengajak orang atau menghimbau agar orang lain selalu menerapkan protokol kesehatan dengan." (DK)

Penelitian serupa yang dilakukan di Mesir juga menunjukkan bahwa partisipan sudah memiliki sikap yang positif dalam penerapan protokol kesehatan COVID-19. Partisipan percaya bahwa dengan mencuci tangan dan meminimalisir kontak dengan orang lain dapat mencegah laju penyebaran COVID-19 (Abdelhafiz et al., 2020). Hal ini berbanding terbalik dengan penelitian yang dilakukan oleh Agus Indra Yudhistira Diva Putra et al yang dalam penelitiannya menyebutkan bahwa masih terdapat masyarakat yang memiliki sikap yang buruk yakni sebanyak 50 orang $(43,9 \%)$ yang cenderung tidak tepat dan salah mengartikan pandemi serta menggunakan pelindung diri tidak tepat seperti menggunakan masker hanya dimulut, berbicara membuka masker, menerima teman dengan bersalaman, dan jarang mencuci tangan setelah kontak dengan permukaan benda (Indra et al., 2020).

Tahap terakhir dari metode CAM adalah monitoring dan evaluasi. Keberlanjutan setelah edukasi kelompok yakni pemantauan dan evaluasi. Evaluasi yang dilakukan bertujuan menilai apakah kegiatan edukasi yang telah dilaksanakan dapat diaplikasikan pada kegiatan wisata yang dipandu oleh POKDARWIS di Desa Burai. Untuk mengidentifikasinya diajukan beberapa pertanyaan perilaku-perilaku dalam kegiatan wisata yang telah dilakukan sebagai upaya pencegahan COVID-19.

\section{Perilaku}

Perilaku merupakan suatu kegiatan atau aktivitas organisme (makhluk hidup) yang bersangkutan. Perilaku manusia pada hakikatnya adalah tindakan atau aktivitas dari manusia itu sendiri yang mempunyai bentangan yang sangat luas antara lain: berjalan, berbicara, menangis, tertawa, bekerja, kuliah, menulis, membaca, dan sebagainya. Dari uraian di atas dapat disimpulkan bahwa perilaku (manusia) adalah semua kegiatan atau aktivitas manusia, baik yang dapat diamati langsung maupun yang tidak dapat diamati oleh pihak luar (Notoatmodjo, 2012).

Perilaku kesehatan sendiri mengandung arti yaitu perilaku orang sehat untuk mencegah penyakit dan meningkatkan kesehatan. Perilaku sehat (healthy behavior) disebut juga sebagai tindakan preventif atau upaya untuk mencegah dari sakit dan masalah kesehatan yang lain dan tindakan promotif atau kegiatan untuk memelihara dan meningkatkannya kesehatannya (Notoatmodjo, 2012).

Evaluasi perilaku pada kegiatan edukasi ini dinilai dari video edukasi dan laporan mengenai kondisi objek yang menjadi tempat wisata. Terjadi peningkatan dari perilaku tidak sehat menjadi perilaku sehat, hal ini ditunjukkan dengan adanya video Kelompok Sadar Wisata yang menghimbau masyarakat untuk menerapkan 3M (Memakai masker, Menjaga jarak aman dan Mencuci tangan) serta video mencuci tangan memakai sabun dan air mengalir di kawasan wisata Desa Burai.

Banyak faktor yang mempengaruhi perilaku yang berhubungan dengan kesehatan, namun kesadaran akan risiko untuk membuat perubahan perilaku masyarakat adalah unsur utama dalam meningkatkan kesehatan individu dan status kesehatan masyarakat agar terhindar dari COVID-19 (Julia M. Alber et al, 2016). Komunikasi media massa dalam hal ini adalah media 
JPPM (Jurnal Pendidikan dan Pemberdayaan Masyarakat), 8 (1), 2021 - 105

Sri Utami, Indri Paradillah, Oktrina Gustanela, Jessica Ginting, Hadi Pratomo

sosial, merupakan komponen mendasar dari banyak strategi promosi kesehatan yang dirancang untuk mengubah perilaku risiko kesehatan (Carl Hanson et al, 2011).

Media sosial memiliki kapasitas untuk menjangkau dan mempengaruhi jutaan orang secara bersamaan. Kekuatan media yang paling jelas terletak pada jumlah individu yang dapat mereka jangkau. Media sosial dapat memengaruhi perilaku individu dan nilai-nilai komunitas yang turut mendukung lingkungan dan individu sehingga perlu untuk mempertahankan kebiasaan atas perubahan perilaku untuk sadar kesehatan. Selain itu, ketika pola pemberian layanan kesehatan terus berubah, media dapat memberikan informasi berharga kepada masyarakat tentang opsi dan sudut pandang lain (Sampurno, Muchammad Bayu Tejo., Kusumandyoko,Tri Cahyo., Islam, 2002).

Media sosial telah menjadi salah satu media untuk edukasi (Kaya, Birinci, Kawash, \& Alhajj, 2020). Edukasi dimulai dari banyaknya informasi dan peluang terjadinya interaksi serta arahan untuk menuju pengembangan informasi ke dalam tautan lain. Hal tersebut menandakan bahwa selain keterkaitannya sebagai media hiburan, media sosial dapat dijadikan sebagai alternatif sumber jawaban untuk pertanyaan keseharian, termasuk info dan pertanyaan tentang COVID-19 (Sampurno, Muchammad Bayu Tejo., Kusumandyoko,Tri Cahyo., Islam, 2002).

Penelitian yang dilakukan oleh Lestari (2020) menyebutkan bahwa masyarakat cenderung cuek dan acuh tak acuh dalam menghadapi pandemi wabah COVID-19 (Lestari, 2020). Oleh karena itu, dibutuhkan strategi untuk meningkatkan kesadaran masyarakat untuk waspada terhadap pandemi COVID-19. Upaya yang dapat dilakukan adalah dengan melakukan edukasi penerapan protokol kesehatan (Rahmawati et al, 2020). Pemberian edukasi ini bukan hal yang sulit namun juga tidak mudah karena dibutuhkan strategi dan wawasan dengan cara tertentu dalam penyampaian materi edukasi terkait penerapan protokol kesehatan COVID-19. Program edukasi terbukti cukup efektif dilaksanakan untuk mempengaruhi perilaku dan meningkatkan pengetahuan partisipan dalam upaya pencegahan dan penyebaran COVID-19 (Zulfa, Fatia., \& Kusuma, 2020). Kegiatan edukasi secara keseluruhan berhasil meningkatkan pengetahuan dan perubahan sikap peserta kegiatan yang sebelumnya tidak tahu atau apatis terhadap COVID19 menjadi tahu dan turut aktif dalam melakukan pencegahan penyebaran COVID-19 di keluarga dan masyarakat (Permatananda, Cahyawati, Aryastuti, \& Udiyani, 2020).

Berdasarkan hasil penelitian yang dilakukan bersama informan dan responden diperoleh peningkatan pengetahuan, sikap, dan perilaku mengenai penerapan protokol kesehatan COVID-19. Perubahan yang terjadi ini dapat terjadi disebabkan oleh berbagai faktor baik itu internal maupun eksternal. Albert Bandura mengungkapkan bahwa walaupun prinsip belajar cukup untuk menjelaskan dan meramalkan perilaku, namun prinsip tersebut harus memperhatikan suatu fenomena penting yang diabaikan oleh paradigma behaviorisme, yaitu bahwa manusia mempunyai kemampuan berpikir dan mengatur tingkah lakunya sendiri (Abdullah, 2019). Bandura menjelaskan dalam model triadic reciprocal determinism ada tiga faktor yang mempengaruhi perilaku seseorang yaitu lingkungan $(\mathrm{E})$, individu $(\mathrm{P})$, dan perilaku (B) itu sendiri (Bandura, 1986). Pada dasarnya, Bandura percaya bahwa perilaku individu dipengaruhi oleh faktor lingkungan dan karakteristik pribadi. Komponen lingkungan terdiri dari lingkungan fisik di sekitar individu yang berpotensi memperkuat rangsangan, termasuk juga lingkungan sosial yaitu orang-orang yang hadir (atau tidak). Lingkungan mempengaruhi intensitas dan frekuensi perilaku, seperti perilaku itu sendiri dapat memiliki dampak terhadap lingkungan (Abdullah, 2019).

Berdasarkan hasil penelitian diketahui bahwa mayoritas responden telah paham mengenai COVID-19 serta bentuk-bentuk pencegahan yang harus dilakukan. Peningkatan pengetahuan ini dipengaruhi oleh informasi mengenai penerapan protokol kesehatan pencegahan COVID-19 yang diberikan ketika edukasi kelompok. Keyakinan bahwa dengan memakai masker, mencuci tangan menggunakan sabun, dan menjaga jarak 1-2 meter mampu mencegah dari terjangkit penyakit COVID-19 pun muncul setelah edukasi kelompok yang mereka ikuti. Selain itu, pengaruh role model pada kelompok ini yang selalu menerapkan 
JPPM (Jurnal Pendidikan dan Pemberdayaan Masyarakat), 8 (1), 2021 - 106

Sri Utami, Indri Paradillah, Oktrina Gustanela, Jessica Ginting, Hadi Pratomo

protokol kesehatan membawa dampak baik pada peningkatan pengetahuan anggota kelompok POKDARWIS mengenai penerapan protokol kesehatan COVID-19.

Bandura melabeli teorinya sebagai teori kognitif sosial didasarkan atas beberapa alasan. Tidak hanya menempatkan manusia mempunyai kemampuan kognitif yang berkontribusi pada proses motivasi manusia, afeksi dan aksi atau tindakan, tetapi juga bagaimana mereka memotivasi dan meregulasi perilaku mereka dan membuat sistem-sistem sosial untuk mengorganisasi dan menstrukturisasi kehidupan mereka (Abdullah, 2019).

Perubahan sikap yang terjadi dapat disebakan oleh beberapa faktor yang saling berkaitan dan mempengaruhi. Hasil penelitian ini menunjukkan bahwa $91 \%$ responden sudah memiliki sikap yang positif terhadap penerapan protokol kesehatan COVID-19. Seluruh responden setuju bahwa setiap orang harus bijak dalam memilah informasi terkait COVID-19 saat ini. Banyak beredar berita-berita palsu yang akhirnya menimbulkan kecemasan dan ketakutan kepada diri sendiri hingga dapat menganggu kesehatan mental. Terganggunya kesehatan mental seseorang dapat menurunkan imunitas tubuh hingga memudahkan virus corona untuk masuk ke dalam tubuh.

Pemberian video cuci tangan saat edukasi berlangsung merupakan suatu proses mengamati dan meniru perilaku dalam proses belajar. Output yang dihasilkan dari pemberian video tersebut yaitu beberapa anggota POKDARWIS sudah mampu berperilaku mencuci tangan dengan benar. Hal ini menunjukkan terjadi peningkatan dari perilaku tidak sehat menjadi sehat.

Bandura menyatakan bahwa perubahan perilaku seseorang dipengaruhi oleh tindakan orang lain (Bandura, 1986). Terdapat hambatan untuk memunculkan perilaku baru di masyarakat antara lain budaya dan keyakinan yang dimiliki masyarakat setempat. Beberapa anggota POKDARWIS menyebutkan bahwa sulit bagi mereka untuk disiplin dalam menjaga jarak. Hal ini disebabkan budaya dan keyakinan sebagian masyarakat itu sendiri terhadap COVID-19, karena sosialisasi kepada masyarakat pun belum banyak dilakukan, khususnya di Desa Burai yang merupakan daerah pedesaan.

Pada kegiatan edukasi ini juga dilakukan pemilihan role model. Pemilihan role model yang jatuh kepada Ketua POKDARWIS ini telah didasarkan atas beberapa pertimbangan antara lain individu tersebut memiliki kewenangan dan kekuasaan untuk membuat keputusan dalam kegiatan ekowisata di Desa Burai. Role model ini diharapkan mampu untuk memberikan arahan dan mempengaruhi anggota lain untuk mengubah perilaku agar selalu disiplin menerapkan protokol kesehatan COVID-19. Perubahan perilaku yang diharapakan adalah perubahan perilaku menjadi kelompok orang yang berperilaku sehat (healthy behavior).

\section{SIMPULAN}

Berdasarkan hasil penelitian menunjukkan bahwa mayoritas responden telah memiliki pengetahuan yang benar mengenai COVID-19 serta bentuk-bentuk pencegahan yang harus dilakukan. Sebagian besar anggota POKDARWIS memiliki sikap yang positif terhadap penerapan protokol kesehatan COVID-19. Beberapa anggota POKDARWIS sudah mampu berperilaku sehat seperti mencuci tangan dengan sabun secara benar. Edukasi kelompok yang dilakukan secara daring melalui aplikasi whatsapp dinilai cukup efektif sebagai media dan sumber untuk mengedukasi masyarakat sebagai upaya promosi kesehatan dalam pencegahan COVID-19 di Indonesia

\section{UCAPAN TERIMA KASIH}

Kami mengucapkan terima kasih kepada Ibu Ni Made Jendri, SKM, M.Si dan dr. Yoslien Sopamena, MKM atas segala bantuan dan dukungan pelaksanaan kegiatan pemberdayaan masyarakat ini. Ucapan terima kasih juga kepada Kelompok Sadar Wisata (POKDARWIS) Desa Burai atas dukungan dan partisipasi pada kegiatan edukasi kelompok serta mahasiswa Pascasarjana Promosi Kesehatan Departemen Pendidikan Kesehatan dan Ilmu Perilaku, 
JPPM (Jurnal Pendidikan dan Pemberdayaan Masyarakat), 8 (1), 2021 - 107

Sri Utami, Indri Paradillah, Oktrina Gustanela, Jessica Ginting, Hadi Pratomo

Fakultas Kesehatan Masyarakat, Universitas Indonesia angkatan 2020 atas saran dan informasi terkait kegiatan pemberdayaan masyarakat.

\section{DAFTAR PUSTAKA}

Abdelhafiz, A. S., Mohammed, Z., Ibrahim, M. E., Ziady, H. H., Alorabi, M., Ayyad, M., \& Sultan, E. A. (2020). Knowledge, Perceptions, and Attitude of Egyptians Towards the Novel Coronavirus Disease (COVID-19). Journal of Community Health, 45(5), 881-89o.

Abdullah, S. M. (2019). Social Cognitive Theory : A Bandura Thought Review Published in 19822012. Journal PSIKODIMENSIA, 18(1), 85-100.

Ali, B. S. (2015). Strategi Pengembangan Fasilitas Guna Meningkatkan Daya Tarik Minat Wisatawan di Darajat Pass (Waterpark) Kecamatan Pasirwangi Kabupaten Garut. Indonesia University of Education.

Bandura, A. (1986). Social Foundations of Thought and Action: A Social Cognitive Theory. American Psychological Association, Prentice-Hall series in social learning theory. Englewood Cliffs, NJ, US: Prentice-Hall, Inc.

BNPB. (2020). Pedoman Perubahan Perilaku Penanganan COVID-19.

Burhan, E. et al. (2020). Pneumonia COVID-19 Diagnosis dan Penatalaksanaan di Indonesia. Jakarta, Indonesia: Perhimpunan Dokter Paru Indonesia.

Carl Hanson et al. (2011). Use and Acceptance of Social Media among Health Educators. American Journal of Health Education, 42(4), 197-204.

Dewiyuliana, D., \& Septiana, N. (2020). Pengaruh Penyebaran Informasi Covid-19 melalui Whatsapp terhadap Kesiapsiagaan Masyarakat dalam Menghadapi Covid-19. Jurnal Ilmiah Permas: Jurnal Ilmiah STIKES Kendal, 11(1), 103-112.

Indra, A., Diva, Y., Sindy, M., Pratiwi, A., Violin, M., Yani, W., Danang, G. R., et al. (2020). Gambaran Karakteristik Pengetahuan, Sikap dan Perilaku Risiko COVID-19 dalam Kerangka Desa Adat di Desa Gulingan, Mengwi, Bali, 9(3), 313-319.

Julia M. Alber et al. (2016). Social Media Self-Efficacy of Health Education Specialists. Health Promotion Practice, 17(6), 915-921.

Kaya, M., Birinci, Ș., Kawash, J., \& Alhajj, R. (2020). Putting Social Media and Networking Data in Practice for Education, Planning, Prediction and Recommendation.

Kementerian Kesehatan Republik Indonesia. (2020a). Keputusan Menteri Kesehatan Republik Indonesia Nomor HK.01.07/MENKES/413/2020 tentang Pedoman Pencegahan dan Pengendalian CORONA VIRUS DISEASE 2019 (COVID-19).

Kementerian Kesehatan Republik Indonesia. (2020b). Pedoman Pemberdayaan Masyarakat dalam Pencegahan COVID-19 di RT/RW/Desa. Jakarta, Indonesia.

Komite Penanganan COVID-19 dan Pemulihan Ekonomi Nasional. (2021). Peta Sebaran COVID19. Retrieved from https://covid19.go.id/peta-sebaran-covid19

Leonita, E., \& Jalinus, N. (2018). Peran Media Sosial Dalam Upaya Promosi Kesehatan: Tinjauan Literatur. INVOTEK: Jurnal Inovasi Vokasional Dan Teknologi, 18(2), 25-34.

Lestari, S. (2020). Sikap Warga Kampung Wisata Warna-Warni (Nani) Terhadap Pandemi COVID-19. Seminar Nasional Psikologi UM.

Miradj, S., \& Sumarno, S. (2014). Pemberdayaan Masyarakat Miskin, Melalui Proses Pendidikan Nonformal, Upaya Meningkatkan Kesejahteraan Sosial di Kabupaten Halmahera Barat. Jurnal Pendidikan dan Pemberdayaan Masyarakat, 1(1), 101.

Moleong, L. (2017). Metodologi Penelitian Kualitatif (Edisi Revisi). Bandung: PT. Remaja Rosdakarya.

Murphy, F. (2012). Community Engagement, Organization and Development for Public Health Practice. New York: Springer Publishing Company, LLC.

Ningrum, M. D., \& Sujarwo, S. (2017). Pemberdayaan Pedagang Pasar Tradisional dalam Pondok Komunitas Belajar di Sanggar Kegiatan Belajar Kabupaten Wonogiri. JPPM (Jurnal Pendidikan dan Pemberdayaan Masyarakat), 4(2), 199-214. 
JPPM (Jurnal Pendidikan dan Pemberdayaan Masyarakat), 8 (1), 2021 - 108

Sri Utami, Indri Paradillah, Oktrina Gustanela, Jessica Ginting, Hadi Pratomo

Notoatmodjo, S. (2012). Promosi Kesehatan dan Perilaku Kesehatan. Jakarta, Indonesia: Rineka Cipta.

Permatananda, P. A. N. K., Cahyawati, P., Aryastuti, A., \& Udiyani, D. (2020). Pemberdayaan Masyarakat Berbasis Daring di Desa Bukian, Bali dalam Upaya Pencegahan Penyebaran COVID-19. Jurnal Peduli Masyarakat, 2, 187-196.

Putra, N. P. (2020). Solusi Pembelajaran Jarak Jauh Menggunakan Aplikasi Zoom dan Whatsapp Groupdi Era New Normal pada Warga Belajar Paket C di Pusat Kegiatan Belajar Masyarakat (PKBM) Bina Insani. Jurnal Pendidikan Ilmu Pengetahuan Sosial Indonesia, 7(2), 162-176.

Rahmawati et al. (2020). Edukasi Protokol Kesehatan dalam Menjalankan New Normal di Masa Pandemik Melalui Media Poster. Seminar Nasional Pengabdian Masyarakat LPPM UMJ.

Sampurno, Muchammad Bayu Tejo., Kusumandyoko,Tri Cahyo., Islam, M. A. (2002). Budaya Media Sosial, Edukasi Masyarakat dan Pandemi COVID-19. Jurnal Sosial dan Budaya Syar$i, 7(6), 529-542$.

Saugi, W., \& Sumarno, S. (2015). Pemberdayaan Perempuan Melalui Pelatihan Pengolahan Bahan Pangan Lokal. Jurnal Pendidikan dan Pemberdayaan Masyarakat, 2(2), 226.

Trisnani. (2017). Pemanfaatan Whatsapp sebagai Media Komunikasi dan Kepuasan dalam Penyampaian Pesan Dikalangan Tokoh Masyarakat. Jurnal Komunikasi, Media dan Informatika, 6(3).

World Health Organization. (2020). Listings of WHO's Response to COVID-19. Retrieved January 21, 2021, from https://www.who.int/news/item/29-06-2020-covidtimeline

World Health Organization. (2021a). Confirmed Cases of COVID-19 in Indonesia 2020. Retrieved January 21, 2021, from https://covid19.who.int/region/searo/country/id

World Health Organization. (2021b). WHO Coronavirus Disease (COVID-19). Retrieved from https://covid19.who.int/

Yanti, B. et al. (2020). Community Knowledge, Attitudes, and Behavior Towards Social Distancing Policy as Prevention Transmission of Covid-19 in Indonesia. Jurnal Administrasi Kesehatan Indonesia, 8(1).

Zulfa, Fatia., \& Kusuma, H. (2020). Upaya Program Balai Edukasi Corona Berbasis Media Komunikasi dalam Pencegahan Penyebaran Covid-19. Jurnal Abdimas Kesehatan Perintis, $2(1), 17-24$. 